\title{
Predator-prey relationships and foraging ecology of a marine apex predator with a wide temperate distribution
}

\author{
Adam Barnett ${ }^{1,2, *}$, Kátya Abrantes ${ }^{1,3}$, John D. Stevens ${ }^{2}$, Jonah L. Yick ${ }^{1}$, \\ Stewart D. Frusher ${ }^{1}$, Jayson M. Semmens ${ }^{1}$ \\ ${ }^{1}$ Tasmanian Aquaculture and Fisheries Institute, Marine Research Laboratories, University of Tasmania, Private Bag 49, \\ Hobart, Tasmania 7001, Australia \\ ${ }^{2}$ CSIRO Marine and Atmospheric Research, GPO Box 1538, Hobart, Tasmania 7001, Australia \\ ${ }^{3}$ Coastal and Estuary Ecosystem Ecology Laboratory, School of Marine and Tropical Biology, James Cook University, \\ Townsville, Queensland 4811, Australia
}

\begin{abstract}
The diet of the broadnose sevengill shark Notorynchus cepedianus was investigated over 3 years from 2 coastal locations in south-east Tasmania: the Derwent Estuary and Norfolk Bay. In general, individuals from both locations consumed the same broad dietary categories (sharks, batoids, teleosts and mammals). However, within these categories, species composition differed. Variations in chondrichthyan prey consumed matched estimations of prey abundance: Mustelus antarcticus was the primary prey in Norfolk Bay, where it was also the most abundant prey species; similarly, Squalus acanthias was an important prey and the most abundant in the Derwent Estuary. A decline in the catch rates of $N$. cepedianus and elasmobranch prey, in particular $M$. antarcticus over 3 years coincided with declines in dietary occurrence of $M$. antarcticus. Also, N. cepedianus and M. antarcticus abundances were both higher in Norfolk Bay than the Derwent Estuary. The correlation with diet and estimations of predator and prey relative abundance suggests $N$. cepedianus may move into coastal areas to exploit regular seasonal abundant resources, but they can also be versatile opportunistic predators that exploit a temporarily abundant resource.
\end{abstract}

KEY WORDS: Shark $\cdot$ Notorynchus cepedianus $\cdot$ Diet $\cdot$ Spatial scale $\cdot$ Mustelus antarcticus Resale or republication not permitted without written consent of the publisher

\section{INTRODUCTION}

Predation is a fundamental factor controlling community dynamics and directly influencing community structure (Williams et al. 2004, Heithaus et al. 2008). With an ever increasing emphasis on multiple species/ecosystem management approaches, understanding predator-prey interactions is important for modelling and predicting ecosystem processes (Yodzis 1994, Bax 1998, Alonzo et al. 2003, Braccini et al. 2005). However, as predation can be highly variable in time (Bax 1998) and space (Simpfendorfer et al. 2001, Wetherbee \& Cortés 2004), studies on feeding ecology need to incorporate both spatial and temporal variation in diet, to evaluate the consistency of predator-prey relationships.

Many shark species are top predators, and are assumed to play important roles in structuring marine communities through top-down regulation of prey (Stevens et al. 2000, Shepherd \& Myers 2005, Myers et al. 2007, Heithaus et al. 2008). However, there is still a lack of detailed information on the feeding ecology for many of these species (Wetherbee \& Cortés 2004, Braccini 2008). Comprehensive trophic information is particularly scarce for mobile species with wide distributions (Wetherbee \& Cortés 2004). For such species, trophic analysis will be affected by the dynamics of natural systems, variations in prey availability and the 
predators' continual movement over relatively large areas (Heithaus 2004, Braccini et al. 2005). Therefore, it is imperative that trophic studies of large mobile predators investigate diets over a number of spatial scales. For example, regional studies should sample multiple habitats, and where possible, larger scale regional comparisons should be made. To date, the lack of spatial and temporal components in trophic studies means that our understanding of predator-prey interactions for many shark species is rudimentary.

The broadnose sevengill shark Notorynchus cepedianus is a mobile species with a wide geographic distribution (Last \& Stevens 2009), for which there have been a number of regional dietary studies (Ebert 1989, 1991, Lucifora et al. 2005, Braccini 2008). It is a high trophic level predator (4.7; Cortés 1999) with a diverse diet that shows ontogenetic dietary shifts from teleosts to elasmobranchs and mammals (Ebert 2002, Lucifora et al. 2005, Braccini 2008). N. cepedianus is one of the major components of the elasmobranch assemblage in the coastal areas of south-east Tasmania, Australia (Barnett et al. in press, unpubl. data). The high abundance in these coastal areas suggests that they have the potential to significantly influence community dynamics through both direct and indirect predatorprey interactions (Lima \& Dill 1990, Creel \& Christianson 2008). Additionally, N. cepedianus may have impacts on commercial shark species (gummy Mustelus antarcticus and school shark Galeorhinus galeus) that use these coastal areas as nursery grounds (Olsen 1954, Stevens \& West 1997). Natural mortality in these areas is unknown and as losses to predation can exceed those from fisheries (Bax 1998), dietary analyses are needed to provide information on the predation pressure exerted by $N$. cepedianus on these species in nursery areas.

The purpose of this study was to investigate temporal and spatial variation in diets of Notorynchus cepedianus in southeast Tasmania and to use this information to infer feeding ecology. To investigate relationships between dietary occurrence and prey availability, the catch rates of chondrichthyan species were compared to their occurrence in the diets of N. cepedianus.

\section{MATERIALS AND METHODS}

Stomach samples were collected from Notorynchus cepedianus from the Derwent Estuary and Norfolk Bay, south-east Tasmania, Australia (Fig. 1), from December 2006 to February 2009. Norfolk Bay is a relatively shallow (average depth $15 \mathrm{~m}$; maximum depth $20 \mathrm{~m})$ semi-enclosed bay that connects to Frederick Henry Bay and Storm Bay before opening to the waters of the continental shelf (Fig. 1). The Derwent Estuary runs through the city of Hobart before also opening into Storm Bay (Fig. 1). The Derwent Estuary is a highly stratified, salt wedge/partially mixed system with a major freshwater input at the estuarine head (Davies \& Kalish 1994). It consistently reaches depths of 20 to $30 \mathrm{~m}$, with a maximum depth of $44 \mathrm{~m}$.

Sharks were caught using bottom-set longlines, set for 4 to $6 \mathrm{~h}$. On hauling the longline, sharks were brought onboard one at a time and their stomachs flushed to obtain stomach samples. Total (TL) and precaudal (PCL) lengths were measured to the nearest $\mathrm{cm}$, and sharks were tagged in the dorsal fin with plastic Jumbo tags (Daltons) before being returned to the water. Additional stomach samples were obtained from commercial fishing vessels operating in Storm Bay and the edge of the continental shelf off the east and south coasts of Tasmania.

Sampling protocol. Stomach flushing was undertaken by restraining the shark while a plastic hose (3 $\mathrm{cm}$ diameter) attached to an electric pump was inserted through the mouth into the stomach. Seawater was pumped into the shark's stomach. Once the stomach was filled with water, the hose was removed and gentle pressure applied to the abdominal region, causing any food items to be regurgitated. Any material regurgitated was collected in a sieve, then bagged and labelled and placed on ice for subsequent analysis. If prey species that are vulnerable to capture from longlines were judged to be recently ingested (i.e. with no signs of digestion), these were excluded from analysis due to the likelihood that they were taken from the longline. Stomach contents were identified to the lowest taxonomic level possible, based on morphological

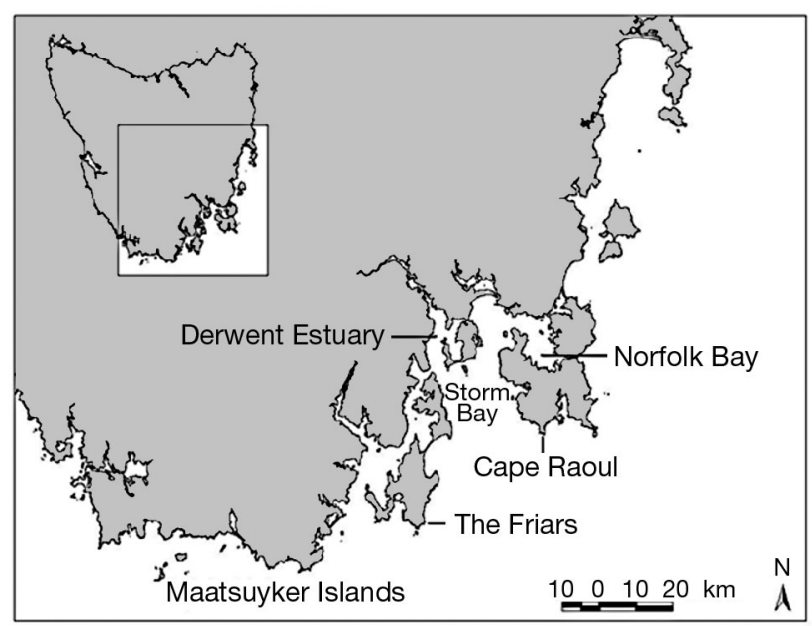

Fig. 1. Notorynchus cepedianus. Sampling locations in the south-east region of Tasmania. The closest seal haul-out sites, Cape Raoul and The Friars, are also indicated 
characteristics of prey, e.g. looking at jaw structures, whole heads, spine characteristics and fin structures and/or shapes. The number of prey of each taxa in each stomach was determined, and wet weights were recorded.

Estimations of prey abundance. To investigate relationships between dietary occurrence and prey availability, the catch rates of chondrichthyan species caught from longlining were compared to their occurrence in the diets of Notorynchus cepedianus. However, this information could only be used as an approximation of any relationship between prey abundance and dietary occurrence as the longlines do not capture all chondrichthyan prey species. For example, smaller batiod species such as the banded stingaree Urolophus cruciatus are not caught on longlines. Also, hook sizes were primarily chosen to catch $N$. cepedianus, which might have reduced the chance of catching smaller prey such as elephantfish Callorhinchus milii. Hook size may also limit the chance of catching neonate Mustelus antarcticus and Galeorhinus galeus, which are approximately $35 \mathrm{~cm}$ TL at birth (Stevens \& West 1997). Longlines consisted of $210 \mathrm{~m}$ of lead-core mainline (8 mm diameter), with $1 \mathrm{~m}$ stainless steel snoods and 50 hooks per line. Two hook types were used: Japanese tuna hooks (No. 328-4) and circle hooks (size 14/0) (ratio: $70 \%$ tuna to $30 \%$ circle hooks). Jack mackerel Trachurus declivis, arrow squid Nototodarus gouldi, redbait Emmelichthys nitidus and Australian salmon Arripis trutta were used as bait in equal proportions for each line. Seasonal longline sampling was conducted at 4 fixed sites in each location (Derwent Estuary and Norfolk Bay). Each location was sampled a minimum of 4 nights (4 lines per night) per season (summer: December to January, autumn: March to May, winter: June to August, spring: September to November) from summer 2006/07 to summer 2008/09. The only exceptions were the first summer and autumn for the Derwent, when it was only possible to sample 2 nights due to weather constraints. Longlines were set between 01:00 and 02:00 $\mathrm{h}$ and hauling began at sunrise (05:00 to 06:00 h).

Data analysis. Stomach contents from all locations were used to examine the overall dietary trends of Notorynchus cepedianus in south-east Tasmania. Frequency of occurrence $(\% F)$, percentage of numerical importance $(\% N)$ and percentage of weight $(\% W)$ metrics were determined (Hyslop 1980). Due to the low sample sizes and the random acquisition of samples from Storm Bay and offshore sites, subsequent quantitative analyses to investigate spatial and temporal differences in diet only considered data collected from Norfolk Bay and the Derwent Estuary. Quantitative analyses were performed on broad dietary groups (mammals, sharks, batoids, chimaera, cephalopods and teleosts) and prey that occurred in $>5 \%$ of stomachs in at least one of the locations (Norfolk Bay or Derwent Estuary), termed as frequently used resource (FUR) (Krebs 1999). In addition to species that occurred in $>5 \%$ of samples being analysed as FUR, smaller skate species (Dentiraja lemprieri, Dipturus confuses and Dipturus sp.) were pooled to represent a single FUR, as were cephalopod species (see Table 1 for FUR). Numerical indices give an indication of the homogeneity of feeding within the population; therefore, \% $N$ was used for quantitative analysis (Hyslop 1980).

Cumulative prey curves. Cumulative prey curves were generated separately for the Derwent Estuary and for Norfolk Bay to determine if the number of stomach samples was enough to describe Notorynchus cepedianus diet at each location. In this analysis, the cumulative number of prey taxa was plotted against the number of stomachs examined. If the curve reaches an asymptotic value, the corresponding number of stomachs is considered adequate for describing the diet. Stomachs were analysed in a random order 999 times. Separate curves were generated for (1) broad, (2) FUR and (3) all species in the diets.

Spatial dietary comparison. The simplified Morisita and Pianka indices (Pianka 1973, Krebs 1999) permutated 999 times (EcoSim version 7.0, Gotelli \& Entsminger 2004) were used to examine the dietary overlap in FUR consumed by sharks from Norfolk Bay and the Derwent Estuary. The degree of overlap is presented in a 0 to 1 scale, where 0 means no overlap and 1 means complete overlap. The graphical method proposed by Amundsen et al. (1996) was also used to evaluate feeding ecology in both locations. In this method, the prey-specific abundance $\left(P_{i}\right)$ is plotted against the $\% F$ (Amundsen et al. 1996). Here, $P_{i}$ is the number of prey $i$ divided by the total number of prey in stomachs in which prey $i$ occurs, and is expressed as a percentage.

One-way analysis of similarity (ANOSIM) was used to test for differences in diet between the Derwent Estuary and Norfolk Bay. Dietary data were square root transformed and the Bray-Curtis similarity matrix was selected. Similarity percentages (SIMPER) were used to identify the prey species or dietary groups that contributed most to any observed differences.

Temporal diet comparison. ANOSIM and SIMPER were also used to investigate temporal variations in diet in Norfolk Bay, by comparing the FUR and 6 broad prey categories over 3 consecutive years (Year 1: December 2006 to May 2007; Year 2: September 2007 to May 2008; Year 3: September 2008 to February 2009). Analysis of annual variations in diets could not be performed for the Derwent Estuary due to the small sample sizes. 
Table 1. Notorynchus cepedianus. Dietary composition from all areas sampled in Tasmania. Total represents all sites combined. Sample size $(\mathrm{n}=$ number of sharks containing prey) is under the area sampled. Frequency of occurrence $(\% F)$, percentage of numerical importance $(\% N)$, percentage of weight $(\% W)$ and the index of relative importance (\%IRI). $\left.{ }^{*}\right)$ Frequently used resource (FUR), noting that skate species Dentiraja lemprieri, Dipturus confuses and Dipturus sp. were pooled to represent a single FUR. -: no data

\begin{tabular}{|c|c|c|c|c|c|c|c|c|c|c|c|c|c|c|c|c|c|c|c|c|}
\hline \multirow[t]{2}{*}{ Prey } & \multicolumn{4}{|c|}{$\begin{array}{l}\text { Total } \\
(\mathrm{n}=203)\end{array}$} & \multicolumn{4}{|c|}{$\begin{array}{l}\text { Norfolk Bay } \\
\quad(n=29)\end{array}$} & \multicolumn{4}{|c|}{$\begin{array}{c}\text { Derwent Estuary } \\
\qquad(\mathrm{n}=49)\end{array}$} & \multicolumn{4}{|c|}{$\begin{array}{l}\text { Storm Bay } \\
(\mathrm{n}=9)\end{array}$} & \multicolumn{4}{|c|}{$\begin{array}{l}\text { Offshore } \\
(\mathrm{n}=16)\end{array}$} \\
\hline & $\% F$ & $\% N$ & & $\%$ IRI & $\% F$ & $\% N$ & & $\%$ IRI & $\% F$ & $\% N$ & $\% W$ & $\%$ IRI & $\% F$ & $\% N$ & $\% W$ & $\%$ IRI & $\% F$ & $\% N$ & $\% W$ & $\%$ IRI \\
\hline Mammalia & 22.7 & 13.1 & 35.5 & 18.9 & 23.6 & 15.1 & 42.6 & 24.3 & 12.2 & 6 & 11.7 & 3.2 & 11 & 3.8 & 26.2 & 5.2 & 61.5 & 11 & 43.2 & 29.2 \\
\hline Pinnipeds* & 15.8 & 9.1 & 29.2 & 35.4 & 14.2 & 9.1 & 35.3 & 28.8 & 8.2 & 4 & 4.8 & 4.6 & 11 & 3.8 & 26.2 & 21.9 & 61.5 & 11 & 43.2 & 76.5 \\
\hline Tursiops truncatus & 3.0 & 1.7 & 4.3 & 1.1 & 4.7 & 3 & 6.4 & 2.0 & - & - & - & & - & - & - & - & - & - & - & - \\
\hline Balaenoptera bonaerensis & 1.0 & 0.6 & 1.5 & 0.1 & - & - & - & - & 4.1 & 2 & 6.9 & 2.3 & - & - & - & - & - & - & - & - \\
\hline Unidentified mammal & 2 & 1.1 & 0.4 & 0.2 & 3.1 & 2 & 0.7 & 0.4 & - & - & - & - & - & - & - & - & - & - & - & - \\
\hline Macropus robustus & 1 & 0.6 & 0.2 & 0.0 & 1.6 & 1 & 0.3 & 0.1 & - & - & - & - & - & - & - & - & - & - & - & - \\
\hline Unidentified elasmobranchs & 7.4 & 4.5 & 0.2 & 2.0 & 7.1 & 5 & 0.1 & 1.7 & 12.2 & 6 & 0.2 & 4.8 & - & - & - & - & - & - & - & - \\
\hline Sharks & 37 & 24.4 & 32.0 & 35.7 & 38.6 & 28.8 & 31.1 & 41.3 & 28.6 & 14.7 & 35.4 & 21.5 & 55.6 & 30.8 & 59.9 & 79.6 & 53.8 & 9.7 & 18.0 & 13.0 \\
\hline Mustelus antarcticus* & 19.2 & 11.6 & 15.4 & 30.3 & 25.2 & 17.2 & 17.6 & 40.1 & 10.2 & 5 & 11.9 & 11.0 & - & - & - & - & 15.4 & 2.8 & 12.9 & 5.5 \\
\hline Galeorhinus galeus & 2 & 1 & 0.9 & 0.2 & 2.4 & 1.5 & 1.4 & 0.3 & - & - & - & - & - & - & - & - & 7.7 & 1.4 & $<0.1$ & - \\
\hline Squalus acanthias* & 8 & 5 & 3.2 & 3.8 & 8.7 & 5.6 & 1.8 & 2.9 & 12.2 & 6 & 6.9 & 10.1 & - & - & - & - & - & - & - & - \\
\hline Notorynchus cepedianus & 2.5 & 1.4 & 8.4 & 1.4 & 2.4 & 1.5 & 7.2 & 1.0 & 2 & 1 & 13.3 & 1.8 & 11 & 3.8 & 22.1 & 18.9 & - & - & - & - \\
\hline Pristiophorus nudipinnis & 0.5 & 0.3 & 0.5 & 0.0 & - & - & - & - & - & - & - & - & 11 & 3.8 & 14.8 & 13.6 & - & - & - & - \\
\hline Cephaloscyllium laticeps & 2 & 1 & 1.0 & 0.2 & 0.8 & 0.5 & 0.9 & 0.1 & 2 & 1 & 1.3 & 0.3 & 22 & 7.7 & 3.5 & 16.4 & - & - & - & - \\
\hline Squalus megalops & 0.5 & 0.3 & 0.2 & 0.0 & - & - & - & & - & - & - & - & - & - & - & - & 7.7 & 1.4 & 1.5 & 0.5 \\
\hline Unidentified shark & 5.9 & 3.7 & 1.3 & 1.7 & 5.5 & 3.5 & 0.9 & 1.1 & 4.1 & 2 & 2.0 & 1.0 & 11 & 3.8 & 0.8 & 3.4 & 15.4 & 2.8 & 2.9 & 2.0 \\
\hline Batoids & 26.6 & 18.5 & 17.5 & 16.4 & 27.6 & 22.7 & 19.9 & 21.0 & 30.6 & 15.7 & 18.3 & 15.6 & 33.3 & 11.5 & 8.2 & 10.4 & 7.7 & 1.4 & 0.7 & 0.1 \\
\hline Myliobatis australis* & 6.9 & 4.3 & 8.1 & 5.0 & 7.9 & 5.6 & 7.8 & 4.8 & 8.2 & 4 & 13.4 & 9.1 & - & - & - & - & - & - & - & - \\
\hline Spiniraja whitleyi ${ }^{*}$ & 7.4 & 4.5 & 6.4 & 4.7 & 10.2 & 7.1 & 9.5 & 7.7 & 2 & 1 & $<0.1$ & 0.1 & 11 & 3.8 & $<0.1$ & 2.8 & - & - & - & - \\
\hline Dentiraja lemprieri* & 2 & 1 & 0.6 & 0.2 & 1.6 & 1.0 & 0.8 & 0.1 & 4.1 & 2 & $<0.1$ & 0.5 & - & - & - & - & - & - & - & - \\
\hline Dipturus confuses* & 1 & 0.6 & 0.4 & 0.1 & - & - & - & - & 2 & 1 & 1.7 & 0.3 & - & - & - & - & 7.7 & 1.4 & 0.5 & 0.3 \\
\hline Dipturus sp. * & 1.5 & 1 & 0.1 & 0.1 & 0.8 & 0.5 & 0.1 & 0.0 & 4.1 & 2 & $<0.1$ & 0.5 & - & - & - & - & - & - & - & - \\
\hline Narcine tasmaniensis & 0.5 & 0.6 & 0.4 & 0.0 & 0.8 & 1 & 0.5 & 0.1 & - & - & - & - & - & - & - & - & - & - & - & - \\
\hline Urolophus cruciatus* & 6.9 & 4.8 & 2.0 & 2.7 & 6.3 & 5.6 & 1.7 & 2.1 & 8.2 & 4 & 2.5 & 3.4 & 11 & 3.8 & 8.7 & 9.1 & - & - & - & - \\
\hline Dasyatis brevicaudata & 0.5 & 0.3 & 0.2 & 0.0 & - & - & - & - & 2.0 & 1 & 1.1 & 0.3 & - & - & - & - & - & - & - & - \\
\hline Unidentified ray & 1 & 1 & 0.5 & 0.1 & 0.8 & 1 & 0.6 & 0.1 & 2.0 & 1 & 0.4 & 0.2 & - & - & - & - & - & - & - & - \\
\hline Unidentified skate & 1.5 & 1 & 0.6 & 0.1 & 1.6 & 1 & 0.7 & 0.1 & 2.0 & 1 & 0.3 & 0.2 & - & - & - & - & - & - & - & - \\
\hline Chimaera & 4.4 & 2.6 & 1.7 & 0.3 & 2.4 & 1.5 & 0.8 & 0.1 & 8.2 & 4 & 4.5 & 1.0 & 11 & 3.8 & 5.9 & 1.7 & 7.7 & 1.4 & $<0.1$ & 0.1 \\
\hline Callorhinchus milii* & 4.4 & 2.6 & 1.7 & 1.1 & 2.4 & 1.5 & 0.8 & 0.3 & 8.2 & 4 & 4.5 & 4.5 & 11 & 3.8 & 5.9 & 7.1 & 7.7 & 1.4 & $<0.1$ & 0.3 \\
\hline Cephalopoda* & 4.9 & 3.4 & 0.3 & 0.3 & 7.1 & 5.6 & 0.3 & 0.7 & 2.0 & 1 & 0.6 & 0.2 & - & - & - & - & - & - & - & - \\
\hline Nototodarus gouldi & 3.4 & 2 & 0.3 & 0.5 & 4.7 & 3 & 0.3 & 0.7 & 2.0 & 1 & 0.6 & 0.2 & - & - & - & - & - & - & - & - \\
\hline Unidentified cephalopod & 1.5 & 1.4 & $<0.1$ & 0.1 & 2.4 & 2.6 & 0.0 & 0.3 & - & - & - & - & - & - & - & - & - & - & - & - \\
\hline Teleosts & 36 & 33.2 & 13.1 & 28.5 & 27.6 & 20.2 & 5.3 & 12.6 & 49 & 50 & 29.4 & 58.5 & 22 & 7.7 & 1.4 & 3.2 & 92.3 & 33.3 & 38.0 & 57.6 \\
\hline Arripis trutta* & 2.5 & 1.4 & 1.1 & 0.4 & 0.8 & 0.5 & 0.4 & 0.0 & 8.2 & 4 & 4.0 & 4.2 & - & - & - & - & - & - & - & - \\
\hline Sardinops neopilchardus* & 3.5 & 2.0 & 0.3 & 0.5 & - & - & - & - & 12.2 & 6 & 1.1 & 5.5 & - & - & - & - & 7.7 & 1.4 & 1.0 & 0.4 \\
\hline Engraulis australis & 0.5 & 1.0 & 0.1 & 0.0 & - & - & - & - & - & - & - & - & - & - & - & - & 7.7 & 1.4 & 1.2 & 0.5 \\
\hline Platycephalus bassensis & 1.5 & 1.0 & 0.1 & 0.1 & 1.6 & 1 & 0.1 & 0.1 & 2 & 1 & 0.1 & 0.1 & - & - & - & - & - & - & - & - \\
\hline Trachurus declivis & 2.0 & 1.7 & 0.3 & 0.2 & 0.8 & 0.5 & $<0.1$ & 0.0 & 2 & 2 & 0.3 & 0.3 & - & - & - & - & 15.4 & 2.8 & 3.0 & 2.0 \\
\hline Thyrsites atun & 0.5 & 0.3 & $<0.1$ & 0.0 & - & - & - & - & - & - & - & - & 11 & 3.8 & 0.5 & 3.1 & 15.4 & 2.8 & $<0.1$ & 1.0 \\
\hline Thunnus alalunga & 0.5 & 0.3 & 0.6 & 0.0 & - & - & - & - & 2 & 1 & 2.9 & 0.5 & - & - & - & - & - & - & - & - \\
\hline Pseudocaranx dentex & 0.5 & 1.0 & 0.1 & 0.0 & - & - & - & - & 2 & 3 & 0.5 & 0.4 & - & - & - & - & - & - & - & - \\
\hline Salmar salar & 2.5 & 1.4 & 2.1 & 0.5 & 4.2 & 2.5 & 2.9 & 1.0 & 2 & 1 & 0.8 & 0.2 & - & - & - & - & - & - & - & - \\
\hline Salmo trutta & 0.5 & 0.6 & 0.1 & 0.0 & - & - & - & - & 0.8 & 2 & $<0.1$ & 0.1 & - & - & - & - & - & - & - & - \\
\hline Aldrichetta forsteri* ${ }^{*}$ & 1.5 & 1.4 & 1.0 & 0.2 & - & - & - & - & 6.1 & 5 & 4.9 & 3.9 & - & - & - & - & - & - & - & - \\
\hline Emmelichthys nitidus & 1.0 & 1.0 & 0.1 & 0.1 & 0.8 & 0.5 & $<0.1$ & 0.0 & - & - & - & - & - & - & - & - & 7.7 & 1.4 & 0.7 & 0.4 \\
\hline Labridae & 1.5 & 1.0 & 0.1 & 0.1 & 1.6 & 1 & $<0.1$ & 0.1 & 2 & 1 & 0.2 & 0.2 & - & - & - & - & - & - & - & - \\
\hline Notolabrus tetricus & 0.5 & 0.3 & 0.1 & 0.0 & 0.8 & 0.5 & 0.2 & 0.0 & - & - & - & & - & - & - & - & - & - & - & - \\
\hline Ladridopsis forsteri* & 2.5 & 1.7 & 0.2 & 0.3 & 1.6 & 1 & 0.1 & 0.1 & 6.1 & 4 & 4.9 & 3.5 & - & - & - & - & - & - & - & - \\
\hline Latris lineata & 0.5 & 0.3 & 0.1 & 0.0 & - & - & - & - & 2 & 1 & 0.4 & 0.2 & - & - & - & - & - & - & - & - \\
\hline Pterygotrigla polymmata & 1.0 & 0.6 & $<0.1$ & 0.0 & - & - & - & - & - & - & - & - & - & - & - & - & 15.4 & 1.4 & 0.3 & 0.6 \\
\hline Odax cyanomelas & 0.5 & 0.3 & 0.1 & 0.0 & 0.8 & 0.5 & 0.2 & 0.0 & - & - & - & - & - & - & - & - & - & - & - & - \\
\hline Pseudophycis bachus & 0.5 & 0.3 & 0.2 & 0.0 & 0.8 & 0.5 & 0.3 & 0.0 & - & - & - & - & - & - & - & - & - & - & - & - \\
\hline Acanthistius ocellatus & 0.5 & 0.3 & 0.1 & 0.0 & 0.8 & 0.5 & 0.1 & 0.0 & - & - & - & - & - & - & - & - & - & - & - & - \\
\hline Seriolella punctata & 0.5 & 0.3 & 0.0 & 0.0 & 0.8 & 0.5 & $<0.1$ & 0.0 & - & - & - & - & - & - & - & - & - & - & - & - \\
\hline Anguilla australis* & 3.4 & 4.5 & 0.1 & 0.9 & - & - & - & & 14.3 & 16 & 7.2 & 21.2 & - & - & - & - & - & - & - & - \\
\hline Conger verreauxi & 2 & 1 & 1.2 & 0.3 & 3.1 & 2 & 0.4 & 0.3 & - & - & - & & - & - & - & - & - & - & - & - \\
\hline Geotria australis & 1 & 0.6 & 0.1 & 0.0 & - & - & - & - & 4.1 & 2 & 0.6 & 0.7 & - & - & - & - & - & - & - & - \\
\hline Unidentified teleost & 10.3 & 6.8 & 1.3 & 4.9 & 9 & 7.6 & 0.5 & 3.3 & 10 & 5 & 0.5 & 3.5 & 11 & 3.8 & 1.4 & 3.8 & 30.8 & 7 & 7.0 & 9.9 \\
\hline
\end{tabular}


Chondrichthyan composition and abundance. Differences in chondrichthyan species composition between Norfolk Bay and the Derwent Estuary were analysed using ANOSIM and SIMPER. For Norfolk Bay, these analyses were also used to investigate temporal variations in chondrichthyan composition among the 3 years. Pearson's correlations were used to investigate relationships between dietary occurrence $(\% F)$ and catch per unit effort (CPUE) of elasmobranch prey over the 3 years in Norfolk Bay. Longline catches were standardised for number of sharks per 50 hooks. In total, 330 longline sets were used in the analysis. Temporal differences in CPUE for Notorynchus cepedianus over the 3 summers were also investigated using a 1-way ANOVA followed by Tukey's HSD test.

\section{RESULTS}

A total of 336 Notorynchus cepedianus stomachs were flushed, from which 180 (54\%) contained prey. An additional 23 stomachs were obtained from fishers. From these 203 total stomach samples, 129 were from Norfolk Bay, 49 from the Derwent Estuary, 9 from Storm Bay and 16 from offshore sites (Table 1). Sharks containing prey ranged in size from 105 to $270 \mathrm{~cm}$ TL. Based on size classes assigned by Braccini (2008) in an ontogenetic dietary study of $N$. cepedianus in southern Australia (small: <90 cm TL; medium: 91 to $170 \mathrm{~cm}$ TL; large: $>170 \mathrm{~cm} \mathrm{TL}), 81 \%$ of the sharks in the present study were in the large size class and $19 \%$ in the medium size class. No individuals of the small size class were caught. The majority of stomach samples contained low numbers of prey. A single prey individual was found in $55 \%$ of stomachs, while $26 \%$ contained 2 items, $12 \% 3$ and $7 \%$ more than 3 prey. Chondrichthyans were present in $68 \%$ of the total stomachs sampled, teleosts in $36 \%$ and mammals in $23 \%$. Sharks, teleosts, batoids and mammals are all important prey of $N$. cepedianus. However, the prominence of each group varied between locations. Sharks were the main prey in Norfolk Bay, teleosts more apparent in the Derwent Estuary and teleosts and pinnipeds at offshore sites (Table 1). Sharks collected in proximity to seal colonies on the Maatsuyker Islands had high proportions of pinnipeds in their diets.

\section{Cumulative prey curves}

When considering the dietary items at a species level, the number of samples collected in this study was not sufficient to explain the diet of Notorynchus cepedianus in the Derwent Estuary or Norfolk Bay (Fig. 2). However, when diet was analysed based on
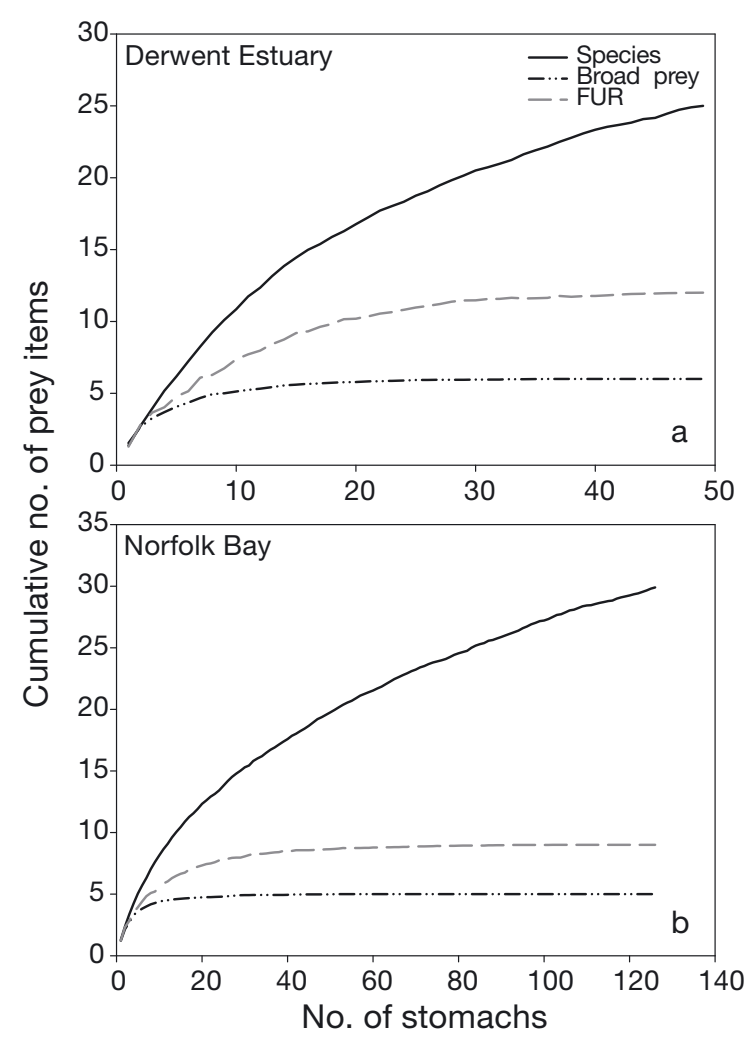

Fig. 2. Notorynchus cepedianus. Cumulative prey curves for the diet of the shark for (a) Derwent Estuary and (b) Norfolk Bay. Three taxonomic prey groups are represented: (1) species; (2) broad prey groups; and (3) frequently used resource species (FUR). Curves are based on the number of prey that occurred $(\% N)$

FUR, the diversity curve for Norfolk Bay and the Derwent Estuary reached an asymptote (Fig. 2). Cumulative curves based on the 6 broad prey categories also reached an asymptote for both locations (Fig. 2).

\section{Spatial dietary comparison}

Based on broad prey categories, there was a high dietary overlap between sharks from the Derwent Estuary and Norfolk Bay (simplified Morisita index: $\left.C_{H}=0.75\right)$. This was reflected in the ANOSIM analysis, which also showed that diets based on broad prey categories did not differ between locations $(\mathrm{R}=0.009, \mathrm{p}=$ 0.27). Both Morisita and Pianka's indexes showed moderate overlap of FUR $\left(C_{H}=0.45, O=0.45\right)$, and there were distinct differences in the FUR used in each location (ANOSIM, $R=0.102, p=0.001$ ). This indicates that while the same broad types of prey were consumed in both locations, there were some differences in the species composition of these groups, which is represented by variation in FUR. 
Mustelus antarcticus, pinnipeds, white spotted spurdog Squalus acanthias and Anguilla australis were the main contributors in observed dissimilarity in diets between locations (SIMPER $46 \%$ cumulative). Overall, Mustelus antarcticus (56\%), Spiniraja whitleyi (8\%) and pinnipeds $(17 \%)$ were the main prey identified in Norfolk Bay and Anguilla australis (20\%), Squalus acanthias (13\%), Myliobatis australis (11\%) and teleosts species $(19 \%)$ were the main contributors in the Derwent Estuary.

The longline CPUE indicated that the relative abundance of the main elasmobranch prey differed between Norfolk Bay and the Derwent Estuary (ANOSIM, $\mathrm{R}=0.234, \mathrm{p}=0.001$ ). SIMPER analysis revealed that the difference in relative abundance of Mustelus antarcticus and Squalus acanthias between the 2 locations were the main factors influencing prey availability in each area (Fig. 3). Relative abundance of elasmobranch prey showed links to the occurrence of prey in the diets of Notorynchus cepedianus in both locations. Mustelus antarcticus and Spiniraja whitleyi were important prey and abundant in Norfolk Bay (Fig. 3, Table 1). Conversely, Squalus acanthias was caught more in the Derwent Estuary and was one of the most important prey in this area (Fig. 3, Table 1). The lower occurrence of Mustelus antarcticus and Spiniraja whitleyi in the Derwent Estuary also matched their reduced occurrence in the diet compared to Norfolk Bay (Fig. 3, Table 1). Galeorhinus galeus was only caught and only featured in the diet in Norfolk Bay (Fig. 3, Table 1). Callorhinchus milii was

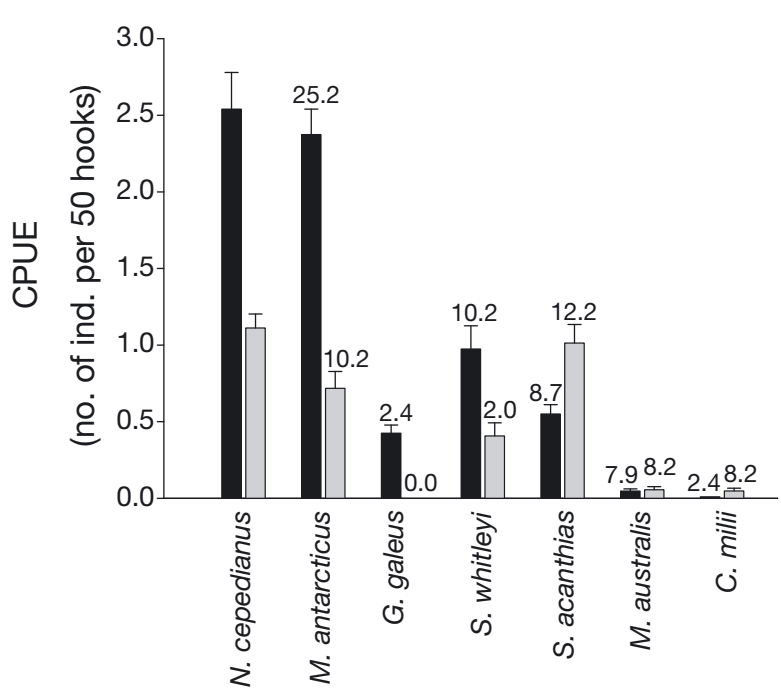

Fig. 3. Catch per unit effort (CPUE $=$ no. of ind. per 50 hooks; $\pm \mathrm{SE}$ ) of chondrichthyan species for Norfolk Bay (black bars) and the Derwent Estuary (grey bars). Number above the histogram represents the percent frequency of occurrence $(\% F)$ in the diet of Notorynchus cepedianus for that location. See Table 1 for full species names only caught and was more prominent in the diet in the Derwent Estuary (Fig. 3, Table 1). Both locations had similar results for Myliobatis australis, they were not caught very often, but they were prominent prey (Fig. 3, Table 1). Additionally, the longlines caught sharks (both G. galeus and Squalus acanthias) as small as $42 \mathrm{~cm}$ TL.

\section{Temporal variability in diet in Norfolk Bay}

The proportion of each FUR consumed differed between the 3 years in Norfolk Bay (ANOSIM, R = $0.061, p=0.004)$. The first year was significantly different from the second (ANOSIM, $R=0.055, p=0.016$ ) and the third (ANOSIM, $R=0.123, p=0.002$ ), but the second was not significantly different from the third (ANOSIM, $R=0.010, p=0.257$ ). The primary differences in diet between years were due to a decrease in Mustelus antarcticus consumed over the 3 years and an increase in pinnipeds, and batoid species Spiniraja whitleyi, Myliobatis australis and Urolophus cruciatus (Fig. 4).

The absence of Notorynchus cepedianus from winter catches and its presence from spring to autumn in Norfolk Bay matches the seasonal catches of its shark prey (Fig. 5). Relative abundance estimates of prey were significantly different over the 3 years of sampling in Norfolk Bay (ANOSIM, R = 0.055, p = 0.007). Differences in prey abundance estimates were primarily driven by a decline in catches of Mustelus

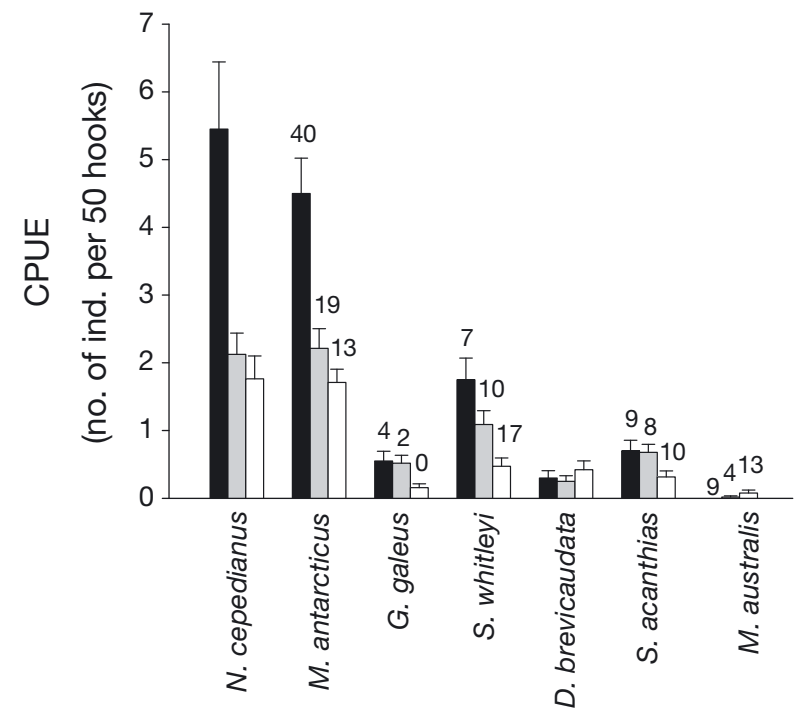

Fig. 4. Catch per unit effort (CPUE = no. of ind. per 50 hooks; $\pm \mathrm{SE}$ ) for Notorynchus cepedianus and its elasmobranch prey for 3 years in Norfolk Bay. Year 1: black bars; Year 2: grey bars; Year 3: white bars. Number above the histogram represents the percent frequency of occurrence $(\% F)$ in the diet of $N$. cepedianus for that year. See Table 1 for full species names 


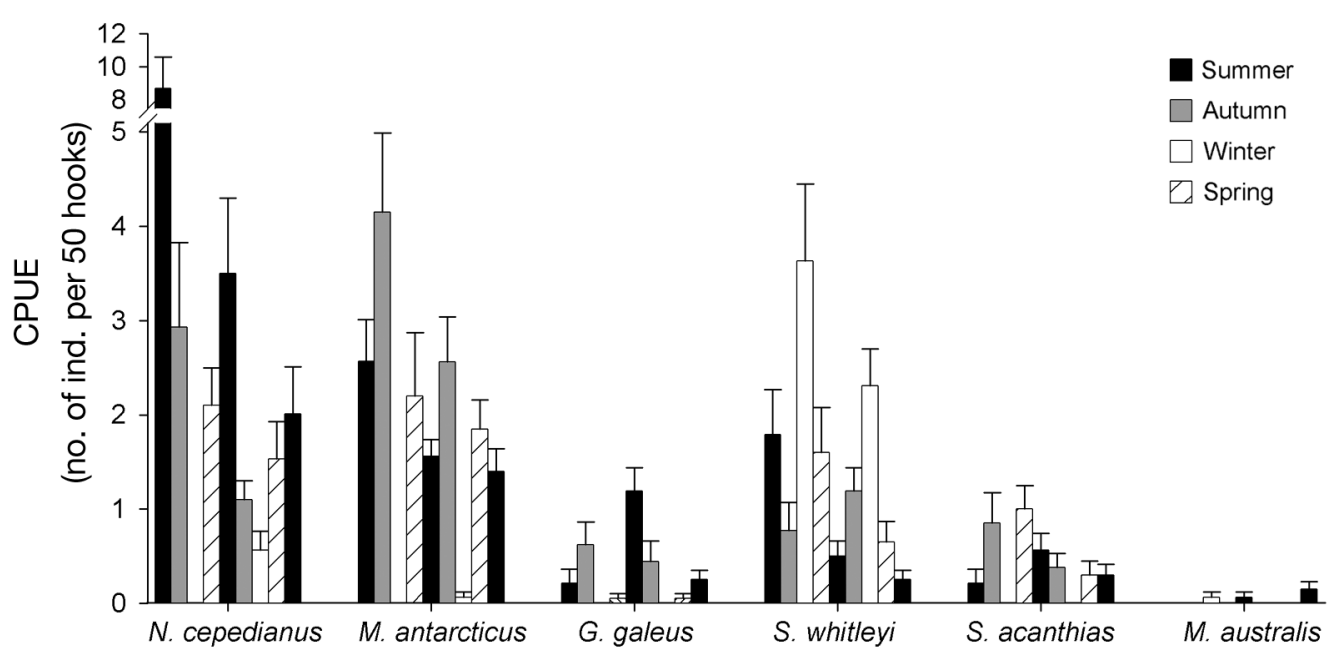

Fig. 5. Catch per unit effort (CPUE = no. of ind. per 50 hooks; \pm SE) of Notorynchus cepedianus and its main chondrichthyan prey per season. Seasons run in sequence from summer 2006/07 through to summer 2008/09. See Table 1 for full species names

antarcticus over the 3 years (Fig. 4). For the first and second years, there was a correlation between the elasmobranch prey abundance and the prey occurrence in the stomachs (Year 1: $\mathrm{R}=0.92, \mathrm{p}=0.028$; Year 2: $\mathrm{R}=0.94, \mathrm{p}=0.016)$. No relationship was however present for the third year $(p=0.6030)$. The significance of the relationship in Years 1 and 2 was mainly driven by the high abundance of Mustelus antarcticus in comparison with other species, and the absence of a significant relationship in year 3 was a result of low abundances of this species in the catches. There was a strong correlation between CPUE and dietary occurrence of Mustelus antarcticus $(\mathrm{R}=0.99, \mathrm{p}=0.027)$ over the 3 years. For the other elasmobranch species (Spiniraja whitleyi, Galeorhinus galeus, Squalus acanthias and Myliobatis australis), there was no relationship between CPUE and dietary occurrence ( $p>0.05)$. In fact, there was a decrease in CPUE in the third year for Spiniraja whitleyi $(\mathrm{p}=0.157)$ (Fig. 4), which was accompanied by an increase in dietary occurrence. This increase in dietary occurrence probably contributed to the lack of a significant relationship between dietary occurrence and CPUE of elasmobranch prey in the third year.

The other notable change in batoid dietary occurrence in the third year was the increase in Urolophus cruciatus from $4 \%$ in the first and second years to $13 \%$ in the third. However, due to the gear's inability to catch U. cruciatus, comparisons of diet composition to catch rates are not possible. The catches of Notorynchus cepedianus also declined over the 3 years $\left(F_{(2,42)}=7.0191, \mathrm{p}=0.0023\right)$ (Fig. 4). CPUE was significantly higher during the first than the third year $(\mathrm{p}=$ $0.0018)$, but there was no difference between the second and the third years ( $\mathrm{p}=0.1484$ ) (Fig. 4).

\section{Feeding tactics}

As the majority of prey are positioned on the left and upper parts of the feeding strategy plots (Fig. 6), the predator population is believed to have a broad niche width (Amundsen et al. 1996). The high prey-specific abundance $\left(P_{i}\right)$ for a number of prey species implies that when they are consumed, they constitute a large proportion of the diet (Fig. 6). This was evident for Myliobatis australis and Urolophus cruciatus in both locations, for Tursiops truncatus in Norfolk Bay and for Squalus acanthias and Anguilla australis in the Derwent Estuary (Fig. 6).

\section{DISCUSSION}

In general, Notorynchus cepedianus from south-east Tasmania displayed a diverse diet that consisted of chondrichthyans, mammals and teleosts. Although these broad prey types were consumed at the 2 primary study locations (Norfolk Bay and Derwent Estuary), there were some differences in prey species composition between areas. In the Derwent Estuary, no single species dominated the diet as did Mustelus antarcticus in Norfolk Bay. This could have been a result of the lower sample size from this location compared to Norfolk Bay, or perhaps variations in prey abundance influenced dietary composition. For example, M. antarcticus was considerably more abundant in Norfolk Bay. Likewise, the high catches of Squalus acanthias in the Derwent Estuary coincide with it being the most frequently consumed chondrichthyan prey in the estuary. Note however, that differences in digestion rates of prey (or tissues) may cause a bias in 


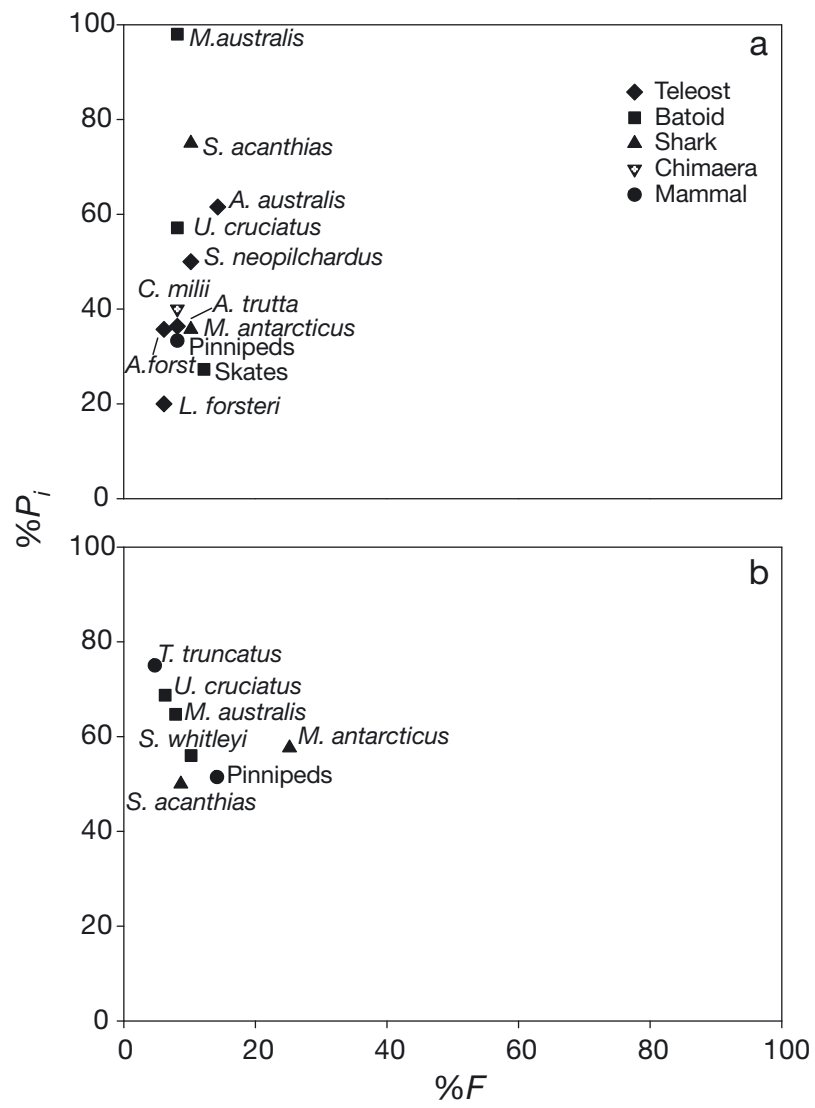

Fig. 6. Notorynchus cepedianus. Feeding strategy plots in (a) the Derwent Estuary and (b) Norfolk Bay. \%F: frequency of occurrence, $\% P_{i}$ : prey-specific abundance. See Table 1 for full species names

which prey were identified, and the failure to identify some prey beyond broad taxonomic groups (e.g. unidentified elasmobranch and teleosts) could possibly influence results regarding the prevalence of the different species in $N$. cepedianus diet. Nevertheless, the vast majority of dietary items were identified to the species level.

Because the sampling gear used in this study does not select equally for all prey species and sizes, a comprehensive comparison of diet and prey abundance is not possible. Bearing in mind that the results predate the current study by over $10 \mathrm{yr}$ and gillnet sampling is also biased by having lower selectivity for batoids, unpublished data from CSIRO gillnet surveys from 1993 to 1995 (see Stevens \& West 1997 for gillnet methods) support the correlations with diet and catches in the present study. For example, Mustelus antarcticus was one of the most common chondrichthyan species caught in Norfolk Bay and Squalus acanthias dominated the catch in the Derwent Estuary in both studies (Fig. 7). The CSIRO data also indicated that the Derwent Estuary had higher abundances of the teleosts species consumed by Noto-
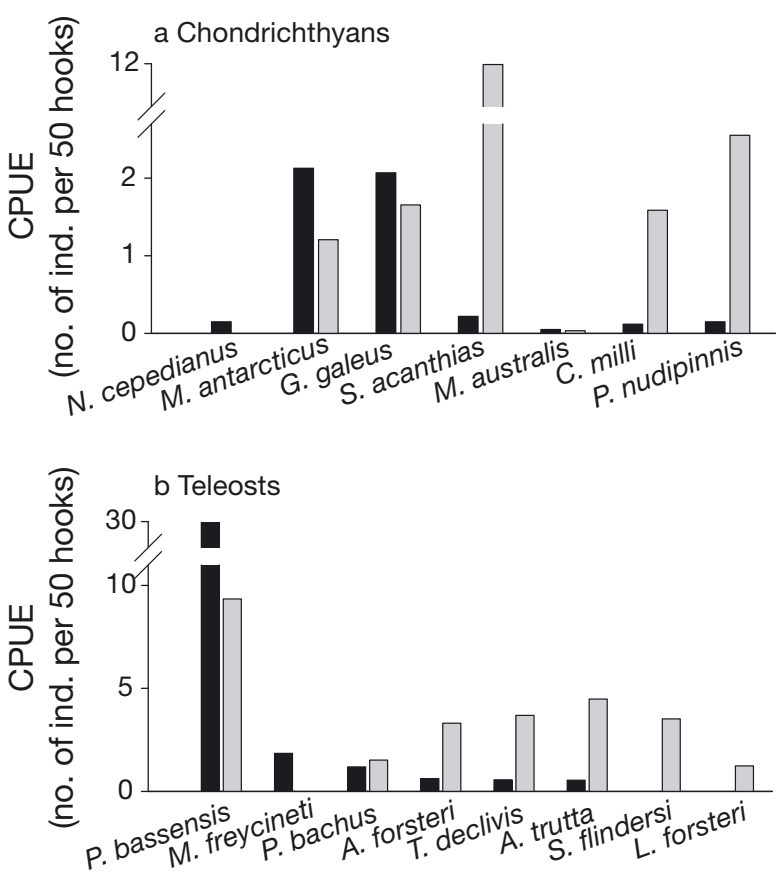

Fig. 7. Catch per unit effort (CPUE $=$ mean no. of ind. per net) of the most abundant (a) chondrichthyans and (b) teleost species in Norfolk Bay (black bars) and the Derwent Estuary (grey bars), collected in the gillnet surveys conducted by CSIRO between 1993 and 1995 (Stevens \& West 1997, J. Stevens \& G. West unpubl. data). $M$. freycineti: Meuschenia freycineti, $S$. flindersi: Sillago flindersi. For other species names see Table 1

rynchus cepedianus than Norfolk Bay (Fig. 7), in particular species such as Aldrichetta forsteri, Arripis trutta and Latridopsis forsteri (Fig. 7). Both sampling methods failed to catch Anguilla australis. However, Anguilla australis are annually abundant in the Derwent Estuary in late spring to summer, when they migrate upriver into fresh water (Sloane 1984). During this time, they were the main prey species in the Derwent. Collectively, these results indicate that $N$. cepedianus diet may be linked to prey abundance.

A potential caveat of this study is that a shark may have fed elsewhere before being caught in the study locations. However, Notorynchus cepedianus tend to spend weeks to months in Norfolk Bay or in the Derwent Estuary (Barnett et al. in press, unpubl. data) suggesting that the majority of prey were captured in the proximity of these sampling sites. The variation in diet over small spatial scales observed in this study highlight the biases which may result when ecosystem models for a specific area use dietary data from other areas. Models may also be biased if they do not consider temporal changes in diet and prey abundance.

For instance, in addition to the spatial differences in diet, there was also a temporal variability in the diet of Notorynchus cepedianus from Norfolk Bay. The decline 
in occurrence of Mustelus antarcticus in the diets over time coincided with a decline in catch rates of both Mustelus antarcticus and N. cepedianus. This may be a result of synchronized population fluctuations (Lundberg et al. 2000), where the decline in Mustelus antarcticus abundance is reflected in the diet and abundance of $N$. cepedianus. Similarly, catch rates of $N$. cepedianus and Mustelus antarcticus were both higher in Norfolk Bay than the Derwent Estuary. Together, these results imply that fluctuations in the number of a normally abundant prey, or total prey, may directly influence the number of predators foraging in the area. The increase of batoid prey in the diet did not coincide with an increase in catches of Spiniraja whitleyi or Myliobatis australis over the 3 years. In fact, the catches of $S$. whitleyi decreased. The low catches of Myliobatis australis over the entire study for the Derwent Estuary and Norfolk Bay does not correlate with their prominence in $N$. cepedianus diet, which implies that fishing gear fails to land them very often, or they are a preferred prey despite being in low abundance. Alternatively, this could be a diet expansion due to other common prey decreasing in abundance.

There is often spatial and temporal variation in the diet of large mobile shark species (Heithaus 2004). However, to what extent is this variation influenced by prey abundance? And, in times of high prey abundance, do generalist predators select a preferred prey, or do they take the first prey encountered? These questions are difficult to answer due to the complexities in measuring prey abundances in marine environments, especially for highly mobile predators such as sharks (Bethea et al. 2004). Previous studies comparing shark diets and prey availability estimates have shown that, during times of high prey abundance, some species (e.g. school shark Galeorhinus galeus and angel shark Squatina dumeril) can be selective predators (Lucifora et al. 2006, Baremore et al. 2008).

In the present study, the correlations between prey abundance and consumption suggest feeding on plentiful resources. The seasonal catch rates of Notorynchus cepedianus and their elasmobranch prey also suggest that $N$. cepedianus may move into coastal regions in spring following the arrival of a number of elasmobranch species including triakids (Mustelus antarcticus and Galeorhinus galeus), and that they depart just prior to triakids migrating out of these areas for winter. The same pattern was observed in Californian bays, where the seasonal occurrence and high abundances of Triakis semifasciata, Mustelus henlei and Myliobatis californica from spring to autumn (Ebert 1986, Smith \& Abramson 1990, Gray et al. 1997, Hopkins \& Cech 2003, Carlisle \& Starr 2009) coincide with $N$. cepedianus migrating into the bays (Ebert 1989). There are many other examples of predators making annual migrations to exploit a known resource. For example bears seasonally feed on salmon migrations (Miller et al. 1997, Reimchen 2000) and large predatory fish and dolphins take advantage of sardine runs (Beckley \& van der Lingen 1999). A number of shark species show similar behaviour. White sharks Carcharodon carcharias seasonally aggregate to feed around pinniped colonies (Bruce 1992, Klimley et al. 2001, Domeier \& Nasby-Lucas 2008) and tiger sharks Galeocerdo cuvier congregate at islets in the French Frigate Shoals to prey on fledging albatross Phoebastria spp. (Tricas et al. 1981, Meyer et al. 2009).

Although sevengills may move into coastal areas to exploit a regular abundant prey such as Mustelus antarcticus and Squalus acanthias, their diverse diets also suggest they are opportunistic. The high \%W of mammals (in particular pinnipeds) suggests that, when available, this high energy food source (Heithaus 2004) may be targeted. Interestingly, the decrease in dietary importance of $M$. antarcticus in the third year of the study in Norfolk Bay correlated with an increase in pinniped prey. Although no mammal surveys were conducted during this study, the absence of Australian fur seal breeding colonies in southern Tasmania and the long distance to the closest major haul-out sites ( 50 to $75 \mathrm{~km}$ ) (Fig. 1) (Hume et al. 2004) suggests seals would probably not be a consistent or abundant resource in Norfolk Bay. In addition, while satellitetracked male seals in south-east Tasmania were coastal in winter, they only spent approximately $2 \%$ of their time in the lower section of the Derwent Estuary and did not enter Norfolk Bay. In summer, when Notorynchus cepedianus are abundant, the tracked seals were absent from coastal areas (Robinson et al. 2008).

Opportunistic behaviour is also demonstrated by Notorynchus cepedianus exploiting a temporally abundant resource that is common in a particular area for a short period, such as Anguilla australis in the Derwent Estuary (Sloane 1984). Predators often switch their diet to feed on a food source that is only available for a short period. Teleosts that are predominately planktivores will briefly switch to target juvenile teleosts during recruitment events (Martin \& Blaber 1983, Baker \& Sheaves 2005) and shortfin mako sharks Isurus oxyrinchus in the North Atlantic seasonally shift from a diet of squid and a range of prevalent teleosts to concentrate their efforts on bluefish Pomatomus saltatrix (Wood et al. 2007).

There were many similarities between the diet of Notorynchus cepedianus in south-east Tasmania and that in other areas of southern Australia (Braccini 2008). Mustelus antarcticus, Myliobatis australis, urolophids and Callorhinchus milii were important prey species in both regions (Appendix 1). Notable differences were the importance of marine mammals in 
Tasmania, and the importance of cephalopods, in particular ommastrephid squid, in southern Australia (Braccini 2008). These differences may be attributed to differences in ecology between the 2 areas. Braccini (2008) obtained samples from commercial fishermen in South Australia and Victoria at depths of 30 to $140 \mathrm{~m}$, whereas most samples used in the present study were collected inshore, in depths of 3 to $20 \mathrm{~m}$. There were also notable differences in the sizes of $N$. cepedianus sampled in each region. Small to medium sized sharks $(<170 \mathrm{~cm} \mathrm{TL})$ dominated the southern Australia study (Braccini 2008), whereas no small $(<90 \mathrm{~cm} \mathrm{TL})$ sharks were caught in Tasmania and a large proportion were in the upper size class ( $>170 \mathrm{~cm}$ TL) (Barnett et al. in press). Since $N$. cepedianus can show ontogenetic dietary shifts from teleosts to elasmobranchs and mammals as they grow (Ebert 2002, Lucifora et al. 2005), the low number of mammals in the southern Australia study could have been a reflection of the relatively low numbers of larger $N$. cepedianus sampled.

Similar dietary patterns were also evident for Notorynchus cepedianus in California, southern Africa and Argentina (Ebert 1989, 1991, 2002, Lucifora et al. 2005). Sharks from the genus Mustelus (Family Triakidae) were the most common prey in all regions, and other triakid species were also important in areas where they occurred (Appendix 1). Although the species differ in each region, there are consistent global-scale predator-prey links between Notorynchus cepedianus, triakid sharks, myliobatid rays and marine mammals (Appendix 1). As larger sharks are often the only predators of mesoconsumers, such as other chondrichthyans and pinnipeds, $N$. cepedianus may perform a similar role in0 regulating meso-consumer population numbers throughout their distribution (Lucas \& Stobo 2000, Heithaus 2004, Lucifora et al. 2009). Both the consistent predator-prey links over large spatial scales and the differences over the finer scales show the importance of incorporating spatial and temporal variability in dietary analysis to explore predator-prey relationships.

\section{CONCLUSION}

Results from this study reinforce the position of Notorynchus cepedianus as a top order predator in coastal temperate systems. Due to the diversity of species in its diet, $N$. cepedianus could be classified as a generalist predator. However, the consistent occurrence of similar prey (i.e. triakids and myliobatids) globally suggests that their foraging behaviour could be more complex.

Further work is however needed to clarify if the consistent predator-prey link with triakids is due to Notorynchus cepedianus moving into these areas to specifically target these prey, or if these prey just happen to be widely available in areas where $N$. cepedianus forages. Although diets are useful to infer predator-prey interactions, for a better understanding of the system, it is ultimately essential to combine abundance estimates and spatial patterns of prey with dietary information of the predator.

Acknowledgements. We thank numerous field assistants, in particular A. Pender, and C. Dudgeon, for advice on the manuscript. This study was supported by grants to A.B. from the Save Our Seas Foundation, Winifred Violet Scott Foundation and the Holsworth Wildlife Research Endowment. All research was conducted with approval from the University of Tasmania Animal Ethics Committee (\#A0009120) and the Department of Primary Industries and Water (Permit \# 8028).

\section{LITERATURE CITED}

Alonzo SH, Switzer PV, Mangel M (2003) An ecosystembased approach to management: using individual behaviour to predict the indirect effects of Antarctic krill fisheries on penguin foraging. J Appl Ecol 40:692-702

Amundsen PA, Gabler HM, Staldvik FJ (1996) A new approach to graphical analysis of feeding strategy from stomach contents data-modification of the Costello (1990) method. J Fish Biol 48:607-614

Baker R, Sheaves M (2005) Redefining the piscivore assemblage of shallow estuarine nursery habitats. Mar Ecol Prog Ser 291:197-213

Baremore IE, Murie DJ, Carlson JK (2008) Prey selection by the Atlantic angel shark Squatina dumeril in the northeastern Gulf of Mexico. Bull Mar Sci 82:297-313

Barnett A, Stevens JD, Frusher SD, Semmens JM (in press) Seasonal occurrence and population structure of the broadnose sevengill shark (Notorynchus cepedianus) in coastal habitats of south-east Tasmania. J Fish Biol

Bax NJ (1998) The significance and prediction of predation in marine fisheries. ICES J Mar Sci 55:997-1030

Beckley LE, van der Lingen CD (1999) Biology, fishery and management of sardines (Sardinops sagax) in southern African waters. Mar Freshw Res 50:955-978

Bethea DM, Buckel JA, Carlson JK (2004) Foraging ecology of the early life stages of four sympatric shark species. Mar Ecol Prog Ser 268:245-264

> Braccini JM (2008) Feeding ecology of two high-order predators from south-eastern Australia: the coastal broadnose and the deepwater sharpnose sevengill sharks. Mar Ecol Prog Ser 371:273-284

Braccini JM, Gillanders BM, Walker TI (2005) Sources of variation in the feeding ecology of the piked spurdog (Squalus megalops): implications for inferring predator-prey interactions from overall dietary composition. ICES J Mar Sci 62:1076-1094

Bruce B (1992) Preliminary observations on the biology of the white shark, Carcharodon carcharias, in South Australian waters. Aust J Mar Freshw Res 43:1-11

Carlisle AB, Starr RM (2009) Habitat use, residency, and seasonal distribution of female leopard sharks Triakis semifasciata in Elkhorn Slough, California. Mar Ecol Prog Ser 380:213-228

Cortés E (1999) Standardized diet compositions and trophic levels of sharks. ICES J Mar Sci 56:707-717

Creel S, Christianson D (2008) Relationships between direct predation and risk effects. Trends Ecol Evol 23:194-201 
Davies PE, Kalish SR (1994) Influence of river hydrology on the dynamics and water-quality of the upper Derwent Estuary, Tasmania. Aust J Mar Freshw Res 45:109-130

> Domeier ML, Nasby-Lucas N (2008) Migration patterns of white sharks Carcharodon carcharias tagged at Guadalupe Island, Mexico, and identification of an eastern Pacific shared offshore foraging area. Mar Ecol Prog Ser 370:221-237

Ebert DA (1986) Observations on the elasmobranch assemblage of San Francisco Bay. Calif Fish Game 72:244-249

Ebert DA (1989) Life history of the sevengill shark, Notorynchus cepedianus (Peron 1807), in two Northern California bays. Calif Fish Game 75:102-112

Ebert DA (1991) Diet of the sevengill shark Notorynchus cepedianus in the temperate coastal waters of Southern Africa. S Afr J Mar Sci 11:565-572

Ebert DA (2002) Ontogenetic changes in the diet of the sevengill shark (Notorynchus cepedianus). Mar Freshw Res 53: $517-523$

Gotelli NJ, Entsminger GL (2004) EcoSim: null models software for ecology, Version 7. Acquired Intelligence \& Kesey-Bean, Jericho, VT. www.garyentsminger.com/ecosim/index.htm (accessed August 2009)

Gray AE, Mulligan TJ, Hannah RW (1997) Food habits, occurrence, and population structure of the bat ray, Myliobatis californica, in Humboldt Bay, California. Environ Biol Fishes 49:227-238

Heithaus MR (2004) Predator-prey interactions. In: Carrier JC, Musick JA, Heithaus MR (eds) Biology of the sharks and their relatives. CRC Press, Boca Raton, FL, p 487-523

Heithaus MR, Frid A, Wirsing AJ, Worm B (2008) Predicting ecological consequences of marine top predator declines. Trends Ecol Evol 23:202-210

Hopkins TE, Cech JJ (2003) The influence of environmental variables on the distribution and abundance of three elasmobranchs in Tomales Bay, California. Environ Biol Fishes 66:279-291

Hume F, Hindell MA, Pemberton D, Gales R (2004) Spatial and temporal variation in the diet of a high trophic level predator, the Australian fur seal (Arctocephaluspusillus doriferus). Mar Biol 144:407-415

Hyslop EJ (1980) Stomach contents analysis - a review of methods and their application. J Fish Biol 17:411-429

Klimley AP, Le Boeuf BJ, Cantara KM, Richert JE and others (2001) The hunting strategy of white sharks (Carcharodon carcharias) near a seal colony. Mar Biol 138:617-636

Krebs CJ (1999) Ecological methodology, 2nd edn. Harper Collins, New York, NY

Last PR, Stevens JD (2009) Sharks and rays of Australia, 2nd edn. CSIRO Publishing, Melbourne

- Lima SL, Dill LM (1990) Behavioral decisions made under the risk of predation-a review and prospectus. Can J Zool 68:619-640

Lucas Z, Stobo WT (2000) Shark-inflicted mortality on a population of harbour seals (Phoca vitulina) at Sable Island, Nova Scotia. J Zool (Lond) 252:405-414

> Lucifora LO, Menni RC, Escalante AH (2005) Reproduction, abundance and feeding habits of the broadnose sevengill shark Notorynchus cepedianus in north Patagonia, Argentina. Mar Ecol Prog Ser 289:237-244

Lucifora LO, Garcia VB, Menni RC, Escalante AH (2006) Food habits, selectivity, and foraging modes of the school shark Galeorhinus galeus. Mar Ecol Prog Ser 315:259-270

> Lucifora LO, Garcia VB, Menni RC, Escalante AH, Hozbor NM (2009) Effects of body size, age and maturity stage on diet in a large shark: ecological and applied implications.
Ecol Res 24:109-118

Lundberg P, Ranta E, Ripa J, Kaitala V (2000) Population variability in space and time. Trends Ecol Evol 15:460-464

Martin TJ, Blaber SJM (1983) The feeding ecology of Ambassidae (Osteichthyes: (Perciformes) in Natal estuaries. S Afr J Zool 18:353-362

> Meyer CG, Clark TB, Papastamatiou YP, Whitney NM, Holland KN (2009) Long-term movement patterns of tiger sharks Galeocerdo cuvier in Hawaii. Mar Ecol Prog Ser 381:223-235

Miller SD, White GC, Sellers RA, Reynolds HV and others (1997) Brown and black bear density estimation in Alaska using radiotelemetry and replicated mark-resight techniques. Wildl Monogr 133:3-55

Myers RA, Baum JK, Shepherd TD, Powers SP, Peterson CH (2007) Cascading effects of the loss of apex predatory sharks from a coastal ocean. Science 315:1846-1850

Olsen AM (1954) The biology migration and growth rate of the school shark, Galeorhinus australis (Macleary) (carcharhanidae) in south eastern Australian waters. Aust J Mar Freshw Res 5:95-104

Pianka ER (1973) The structure of lizard communities. Annu Rev Ecol Syst 4:53-74

Reimchen TE (2000) Some ecological and evolutionary aspects of bear-salmon interactions in coastal British Columbia. Can J Zool 78:448-457

$>$ Robinson S, Gales R, Terauds A, Greenwood M (2008) Movements of fur seals following relocation from fish farms. Aquatic Conserv: Mar Freshw Ecosyst 18:1189-1199

- Shepherd TD, Myers RA (2005) Direct and indirect fishery effects on small coastal elasmobranchs in the northern Gulf of Mexico. Ecol Lett 8:1095-1104

Simpfendorfer CA, Goodreid AB, McAuley RB (2001) Size, sex and geographic variation in the diet of the tiger shark, Galeocerdo cuvier, from Western Australian waters. Environ Biol Fishes 61:37-46

- Sloane RD (1984) Upstream migration by young pigmented freshwater eels (Anguilla australis australis richardson) in Tasmania. Aust J Mar Freshw Res 35:61-73

Smith SE, Abramson NJ (1990) Leopard shark Triakis semifasciata distribution, mortality rate, yield, and stock replenishment estimates based on tagging study in San Francisco Bay. Fish Bull 88:371-381

Stevens JD, West GJ (1997) Investigation of school and gummy shark nursery areas in south eastern Australia. FRDC Project 93/061. CSIRO Marine Research, Hobart

Stevens JD, Bonfil R, Dulvy NK, Walker PA (2000) The effects of fishing on sharks, rays, and chimaeras (chondrichthyans), and the implications for marine ecosystems. ICES J Mar Sci 57:476-494

Tricas TC, Taylor LR, Naftel G (1981) Diel behavior of the tiger shark, Galeocerdo-cuvier, at French Frigate Shoals, Hawaiian Islands. Copeia 1981:904-908

Wetherbee BM, Cortés E (2004) Food consumption and feeding habits. In: Carrier JC, Musick JA, Heithaus MR (eds) Biology of the sharks and their relatives. CRC Press, Boca Raton, FL, p 225-246

Williams TM, Estes JA, Doak DF, Springer AM (2004) Killer appetites: assessing the role of predators in ecological communities. Ecology 85:3373-3384

Wood AD, Collie JS, Kohler NE (2007) Estimating survival of the shortfin mako Isurus oxyrinchus (Rafinesque) in the north-west Atlantic from tag-recapture data. J Fish Biol 71:1679-1695

Yodzis P (1994) Predator-prey theory and management of multispecies fisheries. Ecol Appl 4:51-58 


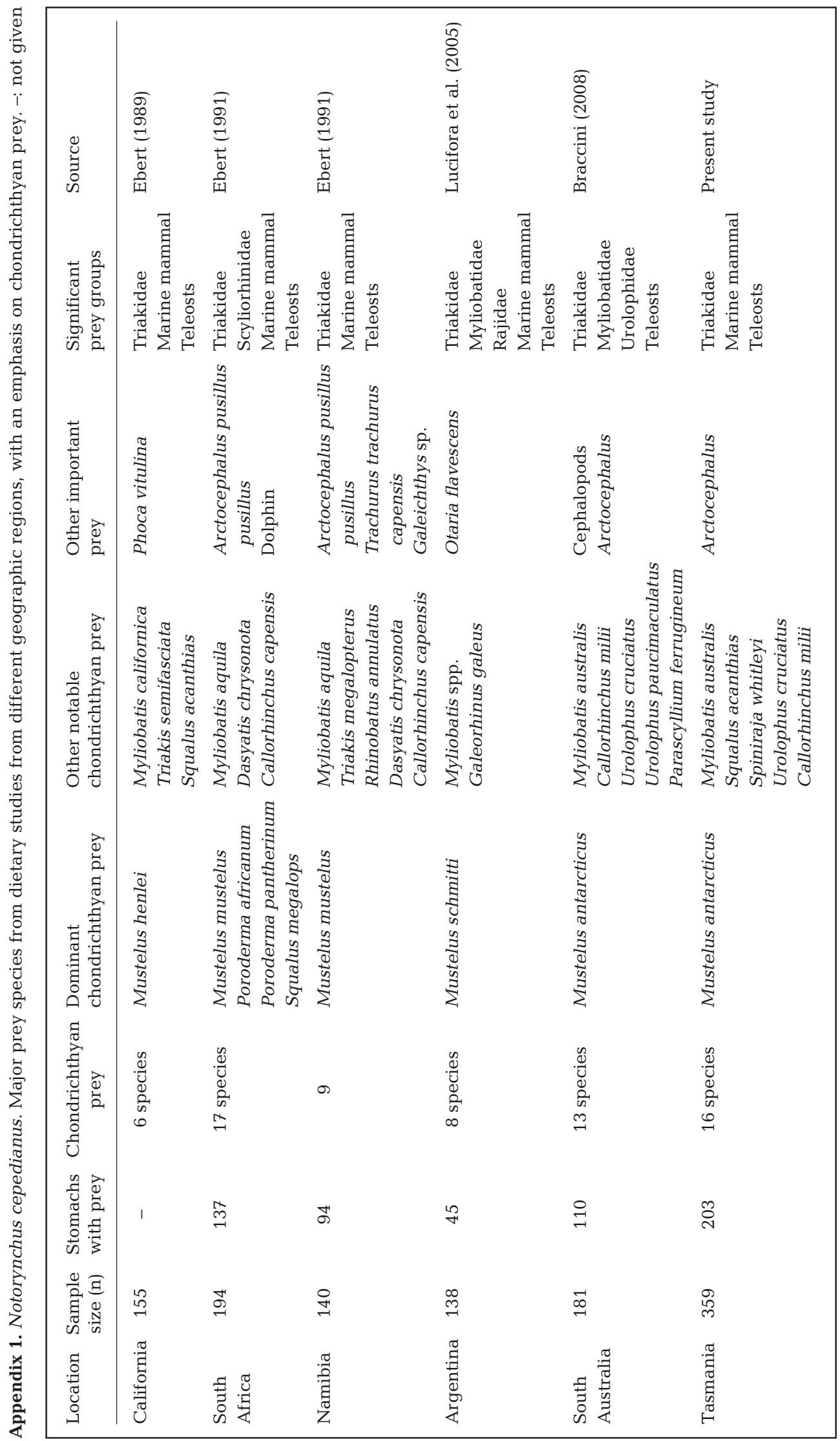

